\title{
UCZELNIE AKADEMICKIE I ICH BIBLIOTEKI W EUROPIE WIEDZY
}

\begin{abstract}
The title refers to the place and role of univer sity libraries in the context of the European Union development policy which evolves together with the competitive challenges on the global knowledge and education market. The goal of the paper is to blow a whistle to signal that the importance of the libraries for building a knowledge potential of the universities participating in those processes is not sufficiently acknowledged or used in the efforts to modernize the country or the Union as a whole. The said importance is merely partially taken into account in the EU and national science policies or the higher education policy. The EU development priorities mentioned in the paper give rise to a number of tasks for Poland in connection with generating, disseminating and transferring knowledge, which could not happen without university libraries. Although these tasks are perceived in Poland, they do not constitute an official priority in the higher education policy, but, instead, a mere proposal of the Ministry of Science and Higher Education.
\end{abstract}

Słowa kluczowe: biblioteki akademickie, uczelnie, polityka szkolnictwa wyższego, Europa Wiedzy

\section{Wprowadzenie}

Problematyka miejsca i roli bibliotek akademickich w Europie wiedzy nie jest nowa. Nie jest także wyczerpana, a to z racji dość rzadkiego w literaturze umiejscawiania jej w kontekście polityki rozwoju Unii Europejskiej, która wszakże ewoluuje wraz z wyzwaniami konkurencyjności na globalnym rynku edukacji i wiedzy. W debacie politycznej i publicznej coraz częściej mówi się o roli uczelni akademickich w globalnym wyścigu do innowacyjności i dobrobytu, którego zasady wyznaczają główne strategie rozwojowe Europy i poszczególnych państw członkowskich. Znaczenie bibliotek dla budowania potencjału wiedzy uczelni wyższych nie jest dostatecznie doceniane, ani wykorzystywane do modernizacji kraju czy Unii jako całości.

Celem artykułu jest zatem zasygnalizowanie, iż owo znaczenie jest uwzględniane w polityce naukowej czy polityce szkolnictwa wyższego, unijnej i krajowej, jedynie pośrednio. Tymczasem bez zasobów bibliotek akademickich nie byłoby możliwe osiąganie ambitnych celów strategicznych - nie byłaby możliwa ani działalność dydaktyczna, ani działalność naukowo-badawcza 
uniwersytetów, zarówno w skali kraju, jak i rozrastającej się skali międzynarodowej. Tym samym nie byłoby możliwe realizowanie ambitnego celu UE, czyli budowania Europy wiedzy.

W roku akcesji Polski do struktur unijnych Biblioteka Główna Politechniki Łódzkiej zorganizowała konferencję zatytułowaną „Polskie biblioteki akademickie w Unii Europejskiej" ${ }^{1}$. We wnioskach z konferencji stwierdzono:

„W referatach oraz wypowiedziach uczestników konferencji wyrażano opinię, że polskie biblioteki akademickie nie różnią się od europejskich w zakresie świadczonych usług (rodzaju udostępnianych materiałów, sposobu realizacji zamówień, dostępu do elektronicznych źródeł informacji, baz danych i e-czasopism), struktury budżetów oraz dążenia do modelu hybrydowego. Pozostają jednak aspekty działalności różniące się nadal od najlepszych wzorców europejskich. Wynika to nie tylko z przyczyn zależnych od bibliotek. Dystans dzielący nas od książnic zachodnich jest wynikiem między innymi sytuacji na rynku wydawnictw, kondycji finansowej kraju i uczelni, braku krajowej polityki informacyjnej oraz tempa implementowania dyrektyw europejskich w prawie polskim",

Skoro 11 lat temu w opinii rodzimych ekspertów polskie biblioteki akademickie nie odstawały poziomem od europejskich instytucji tego typu, czy po ponad dekadzie można zaryzykować tezę, iż polskie biblioteki mają status bibliotek typowych dla Europy wiedzy, Europy, do miana której pretendują kraje członkowskie? Oczywiście w tym artykule nie padnie odpowiedź na to pytanie, gdyż wymagałoby to gruntownej diagnozy stanu bibliotek akademickich w Polsce i analizy porównawczej nie tylko pomiędzy nimi, ale również pokazania ich kondycji na tle bibliotek europejskich. Artykuł ma za zadanie wskazanie, na ile $\mathrm{w}$ europejskiej i polskiej polityce wobec uczelni akademickich biblioteki są traktowane jako swoisty czynnik modernizacyjny swoich uczelni, a pośrednio kraju.

Dagmara Sawicka-Paleolog w jednym z referatów konferencyjnych Polskie biblioteki akademickie $w$ Europie opartej na wiedzy $y^{3}$ postawiła pytanie, czy dla polskich bibliotek akademickich ma jakieś znaczenie polityka unijna ukierunkowana na budowę Europy opartej na wiedzy, zapisana w najważniejszych dokumentach unijnych. Jednocześnie autorka stwierdziła, iż „skarbnice wiedzy w Unii nie są zorganizowane według jednych i tych samych zasad, próżno więc szukać w dokumentach wspólnotowych zapisów regulujących ich funkcjonowanie" ${ }^{4}$. Faktycznie, i dziś trudno o takie bezpośrednie dowody na

\footnotetext{
${ }^{1}$ Informacje na temat konferencji: [dostęp 28.06.2015], http://bg.p.lodz.pl/konferencja 2004/index.html\#A.

${ }^{2}$ Wnioski z konferencji: [dostęp 28.06.15], http://bg.p.lodz.pl/konferencja2004/wnioski. htm.

${ }^{3}$ D. Sawicka-Paleolog, Polskie biblioteki akademickie $w$ Europie opartej na wiedzy, [w:] Polskie biblioteki akademickie w Unii Europejskiej, Łódź 23-25 czerwca 2004 r., materiały konferencyjne, [dostęp: 28.06.2015], http://bg.p.lodz.pl/konferencja2004/pelne_teksty/sawickapaeolog.pdf .

${ }^{4}$ Ibidem, s. 51.
} 
docenienie wpływu bibliotek akademickich na rozwój nauki i edukacji na poziome wyższym. Jednakże, jak już wspomniano, można doszukiwać się pewnych poszlak na rzecz uwzględnienia coraz bardziej nowoczesnej i otwartej na świat działalności bibliotek akademickich w procesie budowania Europy Wiedzy. Sawicka-Paleolog wskazała na tak pożądaną w tym kontekście ewolucję podejścia do bibliotek: „Ciągłe podążanie za rozwojem technologii, wychodzenie naprzeciw potrzebom użytkowników, wzajemna współpraca i promocja roli bibliotek zwłaszcza wewnątrz uczelni, musi w końcu przynieść efekt w postaci nowego spojrzenia na te jednostki"

Po ponad dekadzie słowa te nadal mają charakter postulatywny. Jednakże autorka apeluje: „niech świadomość, że priorytetem są wyższe uczelnie, napawa nas nadzieją na przyszłość”, gdyż „lepsza sytuacja na uczelniach może skutkować lepszymi warunkami dla bibliotek"”.

\section{Europa Wiedzy - wokół pojęcia i jego interpretacji}

Polityczne (czy ideologiczne) i ponadnarodowe pochodzenie pojęcia Europa Wiedzy można przypisać Komunikatowi Komisji Europejskiej z 1997 r., który nosił tytuł W kierunku Europy Wiedzy. Dokument ten akcentował co prawda postulat otwierania głównie europejskiej przestrzeni edukacyjnej, jednak pośrednio odnosił się do takiego rozumienia terminu Europa Wiedzy, które obejmuje oparte na wiedzy społeczeństwo i gospodarkę. Ow społeczny, czy nawet kulturowy, wymiar Europy Wiedzy został przypieczętowany w 1998 r. przez czterech ministrów edukacji - Niemiec, Francji, Włoch i Wielkiej Brytanii - podpisaniem Deklaracji Sorbońskiej, która zainicjowała tworzenie Europejskiego Obszaru Szkolnictwa Wyższego. To deklaracja z Sorbony zaprezentowała Europę Wiedzy jako obszar, w którym uniwersytety mają grać prominentną rolę. Później ten termin przyjął się szerzej w unijnej dokumentacji dotyczącej uniwersytetów, w tym procesu bolońskiego ${ }^{8}$.

W literaturze przedmiotu i dokumentach, zwłaszcza w Polsce, częściej przywoływane są terminy społeczeństwo wiedzy i gospodarka wiedzy. Definiowane osobno te dwa pojęcia dowodzą, że należy odróżniać ich znaczenie w kontekście funkcjonowania uniwersytetów, jak i rozwoju poszczególnych krajów europejskich. Ewa Chmielecka wskazując na rolę uniwersytetów w społeczeństwie wiedzy definiuje krótko owo społeczeństwo jako takie, którego podstawową cechą jest ,zdolność do tworzenia, magazynowania, transferu

\footnotetext{
${ }^{5}$ Ibidem, s. 58.

${ }^{6}$ Ibidem, s. 58.

${ }^{7}$ Ibidem, s. 57.

${ }^{8}$ M.-H. Chou, Å. Gornitzka, Building a European knowledge area: an introduction to the dynamics of policy domains on the rise, [in:] eds. M-H Chou, A. Gornitzka, Building the Knowledge Economy in Europe. New Constellations in European Research and Higher Education Governance, 2014, s. 7-8.
} 
i wykorzystania wiedzy"9. Nie jest to jednak zbyt precyzyjna definicja. W socjologicznych interpretacjach społeczeństwa wiedzy kładzie się bowiem nacisk na powiązanie wiedzy i umiejętności, które dla jednostki stanowią jej kapitał edukacyjny niezbędny do poruszania się na rynku pracy, natomiast dla państwa stanowią zasób modernizacyjny, decydujący o zaawansowaniu w rozwoju społeczno-gospodarczym ${ }^{10}$. Gdy zatem mowa o społeczeństwie wiedzy, podkreśla się te zadania uniwersytetów, które związane są z przekazywaniem wiedzy różnym warstwom społecznym, także w ramach działalności popularyzatorskiej. Uniwersytety mają jednak też inne zadanie, jakim jest transfer wiedzy do przemysłu i znajdowanie dróg jej zastosowania $\mathrm{w}$ gospodarce ${ }^{11}$, co przynależy już raczej do sfery gospodarki opartej na wiedzy. Generalnie jednak uniwersytety łączą oba zadania: społeczne i gospodarcze.

„Zgodnie ze swoją podstawowa misją uniwersytety muszą dostarczać wstępnego kształcenia członków społeczeństwa wiedzy i uczestników gospodarki nastawionej na wiedzę, a zatem powinny dawać potrzebne podstawy wykształcenia technicznego i humanistycznego, umiejętności i możliwość dokształcania się przez całe życie" ${ }^{12}$.

Natomiast Julita Jabłecka pisząc o polityce UE wobec uniwersytetów w budowaniu gospodarki opartej na wiedzy (GOW) i przywołując szereg definicji GOW wymienia też taką, która wskazuje na wzrost sektora wiedzy, ale też nakładów na niego, dominację kapitału intelektualnego, rozwój technologii informacyjnych i telekomunikacyjnych $w$ rozwoju innowacji oraz na rosnącą rolę organizacji w tworzeniu, upowszechnieniu i wdrażaniu wiedzy ${ }^{13}$. Zwraca przy tym uwagę właśnie na powiązane $\mathrm{z}$ realizacją unijnej strategii lizbońskiej z 2000 r. świadome konstruowanie w procesie politycznym warunków umożliwiających rozwój GOW. Autorka opisując politykę unijną wobec uniwersytetów zaznacza, że założeniem reform jest „,stworzenie jednego rynku badawczego, wzmocnienie związku pomiędzy badaniami, edukacją a innowacjami, które ma zwiększyć szanse sukcesu przekształcania wyników badań w technologie komercyjne" ${ }^{\text {14 }}$. Taka optyka dowodzi, iż mamy do czynienia z dominacją gospodarki wiedzy nad społeczeństwem wiedzy ${ }^{15}$.

Jerzy Woźnicki proponuje ujmować Europę wiedzy, społeczeństwo i gospodarkę oparte na wiedzy, w tym społeczeństwo informacyjne, w kategoriach

${ }^{9}$ E. Chmielecka, Rola uniwersytetu w społeczeństwie wiedzy. Uwagi na marginesie dokumentów Unii Europejskiej, [w:] Wzrost gospodarczy i rozwój społeczny jako paradygmaty wspótczesności, red. J. Osiński, Warszawa 2003, s. 539.

${ }^{10}$ Zob. A. Dziedziczak-Foltyn, W kierunku spoteczeństwa wiedzy - cele polityki rozwoju spoteczno-gospodarczego w Polsce, „Przegląd Socjologiczny” nr 3 (2008), s. 123-124.

${ }^{11}$ E. Chmielecka, op. cit., s. 539.

${ }^{12}$ Ibidem, s. 549.

${ }^{13}$ J. Jabłecka, Polityka Unii Europejskiej wobec uniwersytetów w budowaniu gospodarki opartej na wiedzy (GOW), „Przegląd Socjologiczny” nr 57/3 (2008), s. 40-41.

${ }^{14}$ Ibidem, s. 50-51.

${ }^{15}$ Ibidem, s. 52. 
sektora wiedzy. Analizując strukturę tego sektora w ujęciu funkcjonalnym autor wymienia cztery grupy podmiotów:

- $\quad$ instytucje o misji edukacyjnej;

- $\quad$ instytucje o zadaniach naukowo-badawczych i eksperckich;

- $\quad$ instytucje o zadaniach badawczo-wdrożeniowych i koordynacyjnych;

- $\quad$ instytucje zapewniające infrastrukturę informacyjną i usługi promocyjne.

Do tej ostatniej grupy zalicza on instytucje gromadzenia i dystrybucji informacji, $\mathrm{w}$ tym, między innymi biblioteki ${ }^{16}$. Zatem uproszczając można stwierdzić, iż biblioteki akademickie składają się bezpośrednio na sektor wiedzy, pośrednio zaś uczestniczą w budowaniu społeczeństwa i gospodarki wiedzy, czyli Europy Wiedzy, stanowiąc element szerszej infrastruktury uniwersytetów.

Z kolei zdaniem Jo Brysona ${ }^{17}$ gospodarka wiedzy i społeczeństwo wiedzy znaczą więcej niż rynek informacji, w którym sprzedawane są agresywnie produkty i usługi wiedzy. Jest to takie społeczeństwo i gospodarka, w których przedsiębiorstwa, instytucje akademickie oraz sektor przemysłowy współpracują dzieląc się i przetwarzając swoje informacje i wiedzę w ogrom idei, szans i rozwiązań, które kreują ekonomiczne i społeczne bogactwo. Pisząc o perspektywie bibliotek autor ten wskazuje na szereg elementów składających się na społeczeństwo i gospodarkę wiedzy: infrastruktura i dostęp, ludzie i ich dążenia do uczenia się przez całe życie, kultura wiedzy i idee pokoleniowe, innowacje oraz kapitał intelektualny i społeczny, szerzenie informacji poprzez reinwestycje w nowoczesne technologie.

Niewątpliwie zatem biblioteki mają potencjał, by budować środowisko wiedzy, zwłaszcza, że dysponują też niezbędną w erze wiedzy kadrą profesjonalistów. Pracownicy bibliotek są bowiem typowymi pracownikami wiedzy (knowledge workers), którzy w naturalny sposób pracują z informacjami i wiedzą, jak je produkować, jak ich używać i jak je przekazywać. Dlatego sukces Europy opartej na wiedzy zależy nie tylko od europejskich instytucji, narodowych, regionalnych czy lokalnych rządów w całej UE, organizacji biznesowych czy uniwersytetów i bibliotek szkolnych. Zależy on od każdej biblioteki i wysoko wykwalifikowanych bibliotekarzy ${ }^{18}$, czyli profesjonalistów zajmujących się informacją, którzy przyczyniają się do wzmacniania społeczeństwa i gospodarki wiedzy.

${ }^{16}$ J. Woźnicki, Dedykowane normy konstytucyjne i dobre praktyki w realizacji polityki publicznej wobec sektora wiedzy, Kwartalnik SGH „Studia z polityki publicznej” 2014, nr 1, s. 11-31, [dostęp: 29.06.2015], https://ssl-kolegia.sgh.waw.pl/pl/KES/kwartalnik_szpp/Docu ments/polityka\%20publiczna,\%20sektor\%20wiedzy,\%20normy,\%20dobre\%20praktyki.pdf.

${ }^{17} \mathrm{~J}$. Bryson, Measuring the Performance of Libraries in the Knowledge Economy and Society, Australian “Academic \& Research Libraries", vol. 32, issue 4 (2001), s. 332-342, [dostęp: 29.06.2015], http://www.tandfonline.com/doi/pdf/10.1080/00048623.2001.10755171.

${ }^{18}$ K. Materska, Librarians in the knowledge age, "New Library World", vol. 105, iss. 3/4 (2004), s. 145-146. 


\section{Budowanie europejskich obszarów wiedzy jako priorytet polityczny Unii Europejskiej}

Według Marka Kwieka kształt systemów szkolnictwa wyższego zależy od przybierających w ostatniej dekadzie na sile czterech procesów: kształtowania Europejskiego Obszaru Szkolnictwa Wyższego (European Higher Education Area), formowania Europejskiej Przestrzeni Badawczej (European Research Area), formułowania agendy modernizacyjnej wobec uniwersytetów promowanej przez Komisję Europejską oraz wprowadzania w życie unijnej strategii lizbońskiej (a obecnie strategii „Europa 2020”). Ostatni proces ukierunkowany jest na ,przekształcanie gospodarek i społeczeństw europejskich w stronę gospodarek i społeczeństw „opartych na wiedzy” i realizowany w ramach trójkąta edukacja - badania naukowe - innowacje ${ }^{19}$.

Zatem rozwój szkół wyższych, wraz z uniwersytetami, jest niekwestionowanym obecnie priorytetem polityki społeczno-gospodarczej, w tym edukacyjnej, Europy (i Polski), szczególnie w kontekście wieloletnich strategii rozwoju społeczno-gospodarczego Unii Europejskiej - Strategii Lizbońskiej (na lata 2000-2010) oraz strategii „Europa 2020” (na lata 2010-2020). Strategia Lizbońska utorowała uczelniom drogę do szczególnego potraktowania z racji ich roli w tworzeniu i rozpowszechnianiu wiedzy, a tym samym kształtowania społeczeństwa wiedzy i gospodarki opartej na wiedzy. W strategii Europa 2020 ową rolę uczelni wzmocniono poprzez plan tak zwanego inteligentnego rozwoju prowadzącego do budowy gospodarki opartej na wiedzy i innowacji. Ma być on realizowany poprzez ożywienie programu modernizacji szkolnictwa wyższego (programów nauczania, zarządzania i finansowania) oraz wspierania partnerstwa w obszarze wiedzy i umacniania powiązań między światem nauki, biznesu, badań i innowacji ${ }^{20}$.

W ramy ustanowione przez te dwie nadrzędne strategie rozwoju wpisywały się sukcesywnie kolejne dokumenty unijne dotyczące uczelni w Europie Wiedzy, zarówno ich edukacyjnej, jak i badawczej sfery działalności. Opracowany w 2003 r. przez Komisję Europejską w ramach Procesu Bolońskiego dokument Rola uniwersytetów w Europie wiedzy ${ }^{21}$ wyraźnie akcentował wyzwania, jakie stoją przed szkolnictwem wyższym w związku z realizacją celów Strategii Lizbońskiej. Przed uczelniami postawiono zadania związane ze zwiększeniem popytu w sferze edukacji na poziomie wyższym, internacjonalizacją edukacji i badań naukowych, rozwojem ścisłej i efektywnej współpracy

${ }^{19}$ M. Kwiek, Integracja europejska a europejska integracja szkolnictwa wyższego, CPP RPS Volume 17 (2010), [dostęp 30.06.2015], http://www.cpp.amu.edu.pl/pdf/CPP_RPS_vol.17_ Kwiek.pdf.

${ }^{20}$ EUROPA 2020. Strategia na rzecz inteligentnego i zrównoważonego rozwoju sprzyjajacego właczeniu społecznemu KE, Bruksela 3.03.2010, KOM(2010) 2020 wersja ostateczna.

${ }^{21}$ Rola uniwersytetów w Europie wiedzy, KE, Bruksela 5.02.2003, COM(2003) 58 ostateczny. 
pomiędzy uniwersytetami a przemysłem, zwiększeniem liczby miejsc tworzenia wiedzy, reorganizacją wiedzy, a także z pojawieniem się nowych oczekiwań. W 2005 r., na półmetku realizowania celów lizbońskich, opublikowano dokument Mobilizowanie potencjatu umystowego Europy: umożliwianie uniwersytetom wniesienie petnego wkładu do Strategii Lizbońskiej ${ }^{22}$. Podkreślono w nim znaczenie kapitału ludzkiego i innowacyjności w Europie oraz wskazano główne wyzwania stojące przed europejskim szkolnictwem wyższym: osiąganie światowej klasy jakości, poprawę zarządzania oraz zwiększanie i dywersyfikację źródeł finansowania. Komisja Europejska uznała za konieczne możliwie najpełniejsze wykorzystanie instrumentów finansowych UE w celu rozwinięcia przez państwa członkowskie swych sektorów wiedzy (zwłaszcza, że szkolnictwo wyższe nie należy do głównych beneficjentów funduszy strukturalnych i pożyczek udzielanych przez Europejski Bank Inwestycyjny).

Komunikat z 2006 r. Realizacja programu modernizacji dla uniwersytetów: edukacja, badania naukowe i innowacje ${ }^{23}$ wskazywał z kolei na konieczność szeregu działań, wśród których znalazły się: rozwinięcie bardziej skoordynowanej współpracy międzynarodowej wspieranej niezbędnymi funduszami z państwami sąsiadującymi z UE i na całym świecie, postawienie przez uczelnie na większą konkurencję, uznanie przez uczelnie za strategiczne ich związku ze środowiskiem biznesu, zwiększenie mobilności geograficznej i międzysektorowej, czy wykorzystanie możliwości programu uczenia się przez całe życie.

W tym samym roku Komisja Europejska opublikowała Zieloną Księgę: Europejska Przestrzeń Badawcza: Nowe perspektywy ${ }^{24}$. W dokumencie wskazano obszary działań, do których realizacji powinny dążyć państwa członkowskie UE, czyli: właściwy przepływ wykwalifikowanej kadry naukowej, światowej klasy infrastruktura naukowo-badawcza, wysokiej klasy instytucje naukowo-badawcze, skuteczny przepływ wiedzy, skoordynowane programy i priorytety naukowo-badawcze, otwarcie EPB na resztę świata. Zaakcentowano w dokumencie, że uniwersytety jako instytucje działające w obu obszarach - Europejskiej Przestrzeni Badawczej i Europejskiej Przestrzeni Szkolnictwa Wyższego - stoją przed coraz większymi wyzwaniami związanymi z finansowaniem, ale też z organizacją badań naukowych.

W ramach programu modernizacji uniwersytetów Komisja Europejska ogłosiła w 2009 r. komunikat Nowe partnerstwo na rzecz modernizacji uczelni: Forum UE na rzecz dialogu uczelni i przedsiębiorstw ${ }^{25}$. Dokument ten

${ }^{22}$ Mobilizowanie potencjału umystowego Europy: umożliwianie uniwersytetom wniesienie petnego wkładu do Strategii Lizbońskiej, KE, Bruksela 20.04.2005, COM(2005) 152 końcowy $\{$ SEC(2005)518\}.

${ }^{23}$ Realizacja programu modernizacji dla uniwersytetów: edukacja, badania naukowe $i$ innowacje, Komunikat Komisji do Rady i Parlamentu Europejskiego, Bruksela 10.05.2006, $\operatorname{COM}(2006) 208$.

${ }^{24}$ Zielona Księga Europejska Przestrzeń Badawcza: Nowe perspektywy, Bruksela 4.04.2007, KOM(2007) 161 wersja ostateczna.

${ }^{25}$ Nowe partnerstwo na rzecz modernizacji uczelni: Forum UE na rzecz dialogu uczelni $i$ przedsiębiorstw, Komunikat Komisji do Parlamentu Europejskiego, Rady, Europejskiego 
podkreślał jednoznacznie, że uczelnie (to znaczy wszystkie instytucje szkolnictwa wyższego) pełniące trojaką rolę, to jest ośrodków nauczania na najwyższym poziomie, zaawansowanych badań i przełomowych innowacji, stanowią kluczowy element trójkąta wiedzy w Europie. Wśród wielu wyzwań związanych $\mathrm{z}$ modernizacją uczelni wskazana została kwestia transferu wiedzy (poprawy wykorzystywania wyników badań, zwłaszcza finansowanych ze środków publicznych), czy otwarcie uczelni na działania uczenia się przez całe życie.

Wraz z końcem obowiązywania strategii lizbońskiej i pracami nad nową europejską strategią rozwoju Komisja Europejska przygotowała strategię rozwoju szkolnictwa wyższego na następną dekadę. W dokumencie z września 2011 r. Dziatania na rzecz wzrostu gospodarczego i zatrudnienia-plan modernizacji europejskich systemów szkolnictwa wyższego ${ }^{26}$ za niezbędny mechanizm osiągnięcia celu strategii „Europa 2020”, czyli inteligentnego i trwałego wzrostu gospodarczego sprzyjającego włączeniu społecznemu uznano wiedzę, zaś za kluczowe instytucje w procesie realizacji tego celu - instytucje szkolnictwa wyższego. Również Rada Europejska w swoich Konkluzjach Rady w sprawie modernizacji szkolnictwa wyższego ${ }^{27} \mathrm{z}$ grudnia 2011 roku podkreśliła znaczącą rolę uczelni w realizacji unijnych celów rozwojowych. Jednocześnie Rada wezwała państwa członkowskie do promowania innowacji w szkolnictwie wyższym poprzez tworzenie bardziej interaktywnego środowiska edukacyjnego i doskonalenie infrastruktury transferu wiedzy, a także do dzielenia się wiedzą i innowacyjnością ze swoim otoczeniem na rzecz rozwoju regionalnego i lokalnego oraz do rozwijania uczenia się przez całe życie i efektywnego wykorzystywania technologii informacyjno-komunikacyjnych w procesie studiowania.

$\mathrm{W}$ dokumencie z $2012 \mathrm{r}$. Wzmocnione partnerstwo $w$ ramach europejskiej przestrzeni badawczej na rzecz doskonatości i wzrostu gospodarczego ${ }^{28}$ Komisja Europejska zaznaczyła, iż Europejska Przestrzeń Badawcza (EPB) jest centralnym elementem strategii „Europa 2020” i wchodzącej w jej skład inicjatywy przewodniej „Unia innowacji”. Opisując charakter Europejskiej Przestrzeni Badawczej podkreśliła kwestię wzmacniania baz naukowych i technologicznych, niezbędnych dla swobodnej wymiany wiedzy naukowej i technologii

Komitetu Ekonomiczno-Społecznego i Komitetu Regionów, Bruksela 2.04.2009, KOM(2009) 158 wersja ostateczna.

${ }^{26}$ Działania na rzecz wzrostu gospodarczego i zatrudnienia - plan modernizacji europejskich systemów szkolnictwa wyższego, Komunikat Komisji do Parlamentu Europejskiego, Rady, Europejskiego Komitetu Ekonomiczno-Społecznego i Komitetu Regionów, Bruksela 20.09.2011, KOM(2011) 0567 wersja ostateczna.

${ }^{27}$ Konkluzje Rady w sprawie modernizacji szkolnictwa wyższego, (2011/C 372/09), „Dziennik Urzędowy Unii Europejskiej” C 372/36 z 20.12.2011.

${ }^{28}$ Wzmocnione partnerstwo $w$ ramach europejskiej przestrzeni badawczej na rzecz doskonałości i wzrostu gospodarczego, Komunikat Komisji do Parlamentu Europejskiego, Rady, Europejskiego Komitetu Ekonomiczno-Społecznego i Komitetu Regionów, Bruksela 17.07.2012, $\operatorname{KOM}(2012) 392$ wersja ostateczna. 
w kreowaniu konkurencyjności oraz zdolności do wspólnego rozwiązywania wielkich wyzwań. Komisja zidentyfikowała 5 priorytetów EPB, wśród których znalazła się optymalizacja przepływu wiedzy naukowej, dostępu do niej i jej przekazywania, w tym za pośrednictwem cyfrowej EPB - zagwarantowanie wszystkim zainteresowanym stronom możliwości dostępu do wiedzy i jej wykorzystywania. W streszczeniu oceny skutków dotyczącym Europejskiej Przestrzeni Badawczej KE wezwała do działań ukierunkowanych na ukończenie w 2014 r. zapoczątkowanej w 2000 r. EPB. Jako jedną z przeszkód utrudniających osiągnięcia w dziedzinie badań naukowych EPB Komisja wskazała ograniczony obieg wiedzy naukowej i nierównomierny dostęp do tej wiedzy ${ }^{29}$. W 2014 r. w ocenie postępów prac nad EPB Komisja Europejska odniosła się między innymi do realizacji priorytetu dotyczącego optymalizacji przepływu wiedzy naukowej, dostępu do niej i jej przekazywania, w tym za pośrednictwem cyfrowej EPB. Zgodnie $z$ oceną KE, w zakresie otwartego dostępu do publikacji i danych nadal istnieje szereg rzeczywistych i postrzeganych barier, w tym o charakterze prawnym, technicznym, finansowym, społeczno-kulturowym i związanym z zaufaniem. Komisja zwróciła też uwagę, że choć większość państw członkowskich ma wdrożone mocne mechanizmy politycznego wspierania transferu wiedzy, nie znajduje to odzwierciedlenia we wsparciu finansowym w połowie państw członkowskich. W przypadku cyfrowej EPB Komisja wskazała, że infrastruktura gwarantująca dostęp do wiedzy i jej przyswajanie przez wszystkich, służąca otwartemu dostępowi do wyników badań finansowanych ze środków publicznych, nie jest odpowiednio rozwinięta ${ }^{30}$.

\section{Zamiast podsumowania - biblioteki w polityce Unii Europejskiej i Polski}

Analiza dokumentów strategicznych wytyczających kierunki rozwoju Europy Wiedzy prowadzi do wniosku, że biblioteki akademickie nie są wyodrębnione jako osobny element infrastruktury uczelni przyczyniający się w sposób szczególny do realizacji przez szkoły wyższe postulatu tworzenia społeczeństwa i gospodarki opartych na wiedzy. W bogatej dokumentacji unijnej jest jednak uwypuklona kwestia generowania, upowszechniania i transferu wiedzy - procesów, których bez udziału bibliotek i ich coraz szerzej udostępnianych zasobów nie można by przeprowadzić.

${ }^{29}$ DOKUMENT ROBOCZY SŁUŻB KOMISJI STRESZCZENIE OCENY SKUTKÓW Towarzyszący dokumentowi Komunikat Komisji dla Parlamentu Europejskiego, Rady, Europejskiego Komitetu Ekonomiczno-Społecznego i Komitetu Regionów Wzmocnione partnerstwo w ramach europejskiej przestrzeni badawczej na rzecz doskonatości i wzrostu gospodarczego, Bruksela, 17.7.2012 r., KOM(2012) 392 wersja ostateczna.

${ }^{30}$ Europejska przestrzeń badawcza Sprawozdanie z postępu prac za 2014 r., Komunikat Komisji do Rady i Parlamentu Europejskiego, Bruksela, 15.9.2014 r. KOM(2014) 575 wersja ostateczna. 
Więcej odniesień wprost do bibliotek znaleźć można w dokumentach ilustrujących politykę szkolnictwa wyższego w Polsce. Na przełomie lat 2009/2010, na fali unijnych procesów reformowania szkolnictwa wyższego, przygotowano dwa konkurujące ze sobą projekty strategii rozwoju szkolnictwa wyższego, tak zwany środowiskowy (rektorski) i rządowy (ekspercki). Choć Ministerstwo Nauki i Szkolnictwa Wyższego przez blisko pięć lat nie przyjęło żadnego $\mathrm{z}$ nich, stanowią one pewną bazę dla opracowywanego od kliku lat programu rozwoju szkolnictwa wyższego ${ }^{31}$. Projekt opracowany na zlecenie ministerstwa przez Ernst \& Young oraz Instytut Badań nad Gospodarką Rynkową ${ }^{32}$ uwzględnił biblioteki wyłącznie w odniesieniu do upowszechnienia wiedzy przez rozwój bibliotek, jednak była to jedynie drobna wzmianka towarzysząca kwestii świadczenia przez państwo wysokiej jakości usług w obszarze edukacji, badań oraz innych usług publicznych.

Więcej uwagi poświęcił bibliotekom projekt strategii przygotowany przez Fundację Rektorów Polskich ${ }^{33}$. Autorzy wspomnieli o bibliotekach w kontekście celu CO2.2, punkt 7 ,Stworzenie - na poziomie kraju - nowoczesnej infrastruktury informacyjnej, wspierającej system kształcenia" ${ }^{\text {"34, }}$, wskazując na stworzenie bibliotek i sieci portali otwierających dostęp do odpowiednio wybranych i sklasyfikowanych zasobów edukacyjnych. Podkreślili również w punkcie 10 celu CO4.2 „Poprawa systemu wspierania działalności naukowo-badawczej i rozwojowej na uczelniach"35 - konieczność zapewnienia, w wyniku działań ministerstwa, pracownikom naukowym, doktorantom i studentom uczelni szerokiego, bezpośredniego dostępu do informacji naukowej (biblioteki cyfrowe i specjalistyczne bazy wiedzy). W ramach zaś celu CO7.3 „Podniesienie efektywności zarządzania szkołą wyższą" cały punkt 6 poświęcono zwiększeniu efektywności systemów biblioteczno-informacyjnych w uczelniach, koncentrując się na kwestiach cyfryzacji zasobów, finansowania i zarządzania ${ }^{36}$. Trudno uznać to za dowód zmieniającego się podejścia decydentów rządowych do bibliotek akademickich, gdyż oba dokumenty nie są obowiązujące. Niemniej propozycja środowiskowa świadczy o tym, iż rola

${ }^{31} \mathrm{Z}$ raportu NIK z 2010 roku, w którym zarzucono brak przyjętej strategii rozwoju szkolnictwa wyższego do roku 2020 wynika, że MNiSW podjęło decyzję o rozpoczęciu prac nad dokumentem strategicznym „Program rozwoju szkolnictwa wyższego”, zob: NIK, Informacja o wynikach kontroli wykorzystania środków publicznych przez szkoty wyższe KNO-410102/00/2010, [dostęp 6.07.2015], https://www.nik.gov.pl/plik/id,3312,vp,4188.pdf, s. 20.

${ }^{32}$ Strategia rozwoju szkolnictwa wyższego w Polsce do 2020 roku - drugi wariant, Warszawa 2010, s. 20, [dostęp 6.07.2015], http://www.nauka.gov.pl/g2oryginal/2013_05/59579f 9e6efaec82014d6d5be081ca23.pdf.

${ }^{33}$ Strategia rozwoju szkolnictwa wyższego: 2010-2020 - projekt środowiskowy, Konferencja Rektorów Akademickich Szkół Polskich, Fundacja Rektorów Polskich, Warszawa 2009, [dostęp 6.07.2015], http://www.krasp.org.pl/pliki/fdc2bf4809b691e28546a48f8451c42f.pdf.

\footnotetext{
${ }^{34}$ Ibidem s. $79-80$.

${ }^{35}$ Ibidem s. 89.

${ }^{36}$ Ibidem s. 114.
} 
bibliotek w modernizowaniu uczelni w Polsce jest dostrzegana przez środowisko akademickie. Inna rzecz, czy będzie uwzględniana formalnie w dokumentach uchwalanych przez rządzących.

\section{Bibliografia}

Bryson J., Measuring the Performance of Libraries in the Knowledge Economy and Society, Australian "Academic \& Research Libraries", vol. 32, issue 4 (2001), s. 332-342, [dostęp: 29.06.2015], http://www.tandfonline.com/doi/pdf/10.1080/00048623.2001.10755171.

Chmielecka E., Rola uniwersytetu w społeczeństwie wiedzy. Uwagi na marginesie dokumentów Unii Europejskiej, w: red. J. Osiński, Wzrost gospodarczy i rozwój społeczny jako paradygmaty wspótczesności, Warszawa 2003, s. 539-553.

Chou M-H., Gornitzka Å., Building a European knowldge area: an introduction to the dynamics of policy domains on the rise, in: eds. M-H Chou, A. Gornitzka, Building the Knowledge Economy in Europe. New Constellations in European Research and Higher Education Governance, UK \&USA, 2014, s. 1-26.

Dziedziczak-Foltyn A., W kierunku społeczeństwa wiedzy - cele polityki rozwoju społecznogospodarczego w Polsce, „Przegląd Socjologiczny” nr 3 (2008), s. 121-144.

Jabłecka J., Polityka Unii Europejskiej wobec uniwersytetów w budowaniu gospodarki opartej na wiedzy (GOW), „Przegląd Socjologiczny” nr 57/3 (2008), s. 37-58.

Kwiek M., Integracja europejska a europejska integracja szkolnictwa wyższego, CPP RPS Volume 17 (2010), [dostęp 30.06.2015], http://www.cpp.amu.edu.pl/pdf/CPP_RPS_vol.17_ Kwiek.pdf.

Materska K., Librarians in the knowledge age, "New Library World", vol. 105, iss. 3/4 (2004), s. $145-146$.

Sawicka-Paleolog D., Polskie biblioteki akademickie w Europie opartej na wiedzy, [w:] Polskie biblioteki akademickie w Unii Europejskiej, Łódź 23-25 czerwca 2004 r., materiaty konferencyjne, [dostęp: 28.06.2015], http://bg.p.lodz.pl/konferencja2004/pelne_teksty/ sawicka-paeolog.pdf .

Woźnicki J., Dedykowane normy konstytucyjne i dobre praktyki w realizacji polityki publicznej wobec sektora wiedzy, Kwartalnik SGH „Studia z polityki publicznej” (2014), nr 1 (1), s. 11-31, [dostęp: 29.06.2015], https://ssl-kolegia.sgh.waw.pl/pl/KES/kwartalnik_szpp/ Documents/polityka\%20publiczna, $\% 20$ sektor\%20wiedzy,\%20normy, $\% 20$ dobre\%20prakty ki.pdf.

\section{Wykaz dokumentów}

DOKUMENT ROBOCZY SŁUŻB KOMISJI STRESZCZENIE OCENY SKUTKÓW Towarzyszący dokumentowi Komunikat Komisji dla Parlamentu Europejskiego, Rady, Europejskiego Komitetu Ekonomiczno-Społecznego i Komitetu Regionów Wzmocnione partnerstwo w ramach europejskiej przestrzeni badawczej na rzecz doskonałości i wzrostu gospodarczego, Bruksela, 17.7.2012 r. , $\operatorname{KOM}(2012) 392$ wersja ostateczna, [dostęp: 29.06.2015], http://eur-lex.europa.eu/legal-content/PL/TXT/PDF/?uri=CELEX:52012SC0 211\&from=PL.

Działania na rzecz wzrostu gospodarczego i zatrudnienia - plan modernizacji europejskich systemów szkolnictwa wyższego, Komunikat Komisji do Parlamentu Europejskiego, Rady, Europejskiego Komitetu Ekonomiczno-Społecznego i Komitetu Regionów, Bruksela 20.09.2011, $\operatorname{KOM}(2011) 0567$ wersja ostateczna, [dostęp: 29.06.2015], http://eurlex.europa.eu/legal-content/PL/TXT/?uri=CELEX:52011DC0567. 
EUROPA 2020. Strategia na rzecz inteligentnego $i$ zrównoważonego rozwoju sprzyjającego właczeniu społecznemu (EUROPE 2020. A European strategy for smart, sustainable and inclusive growth) KE, Bruksela 3.03.2010, $\mathrm{KOM}(2010) 2020$ wersja ostateczna, [dostęp: 29.06.2015], http://ec.europa.eu/eu2020/pdf/1_PL_ACT_part1_v1.pdf.

Europejska przestrzeń badawcza Sprawozdanie z postępu prac za 2014 r., Komunikat Komisji do Rady i Parlamentu Europejskiego, Bruksela, 15.9.2014 r. KOM(2014) 575 wersja ostateczna, [dostęp: 29.06.2015], http://ec.europa.eu/transparency/regdoc/rep/1/2014/PL/1 2014-575-PL-F1-1.Pdf.

Konkluzje Rady w sprawie modernizacji szkolnictwa wyższego, (2011/C 372/09), dziennik Urzędowy Unii Europejskiej C 372/36 z 20.12.2011, [dostęp: 29.06.2015], http://konfe rencje.frse.org.pl/img/default/Mfile/437/file.pdf.

Mobilizowanie potencjału umysłowego Europy: umożliwianie uniwersytetom wniesienie petnego wktadu do Strategii Lizbońskiej, KE, Bruksela 20.04.2005, COM(2005) 152 końcowy \{SEC(2005)518\}, [dostęp: 29.06.2015], http://eur-lex.europa.eu/legal-content/PL/TXT/ $\mathrm{PDF} /$ ?uri=CELEX:52005DC0152\&from=PL.

NIK, Informacja o wynikach kontroli wykorzystania środków publicznych przez szkoły wyższe KNO-4101-02/00/2010, [dostęp: 29.06.2015], https://www.nik.gov.pl/plik/id,3312,vp,41 88.pdf.

Nowe partnerstwo na rzecz modernizacji uczelni: Forum UE na rzecz dialogu uczelni i przedsiębiorstw, Komunikat Komisji do Parlamentu Europejskiego, Rady, Europejskiego Komitetu Ekonomiczno-Społecznego i Komitetu Regionów, Bruksela 2.04.2009, KOM(2009) 158 wersja ostateczna, [dostęp: 29.06.2015], http://eur-lex.europa.eu/legal-content/PL/TXT/ $\mathrm{PDF} /$ ?uri=CELEX:52009DC0158\&from=PL.

Realizacja programu modernizacji dla uniwersytetów: edukacja, badania naukowe i innowacje, Komunikat Komisji do Rady i Parlamentu Europejskiego, Bruksela 10.05.2006, COM (2006) 208, [dostęp: 29.06.2015], http://archiwum-ukie.polskawue.gov.pl/HLP/files.nsf/0/ C39BBF605345267CC12571C60036DCDE/\$file/modernizacja_dla_uniwersytetow.pdf? Open.

Rola uniwersytetów w Europie wiedzy, KE, Bruksela 5.02.2003, COM(2003) 58 ostateczny, [dostęp: 29.06.2015], http://eur-lex.europa.eu/legal-content/PL/TXT/?uri=uriserv:c11067.

Strategia rozwoju szkolnictwa wyższego w Polsce do 2020 roku - drugi wariant, Warszawa 2010, [dostęp: 29.06.2015], https://www.nauka.gov.pl/g2oryginal/2013_05/59579f9e6 efaec82014d6d5be081ca23.pdf.

Strategia rozwoju szkolnictwa wyższego: 2010-2020 - projekt środowiskowy, Konferencja Rektorów Akademickich Szkół Polskich, Fundacja Rektorów Polskich, Warszawa 2009, [dostęp: 29.06.2015], http://www.krasp.org.pl/pl/strategia/strategia.

Wzmocnione partnerstwo $w$ ramach europejskiej przestrzeni badawczej na rzecz doskonatości i wzrostu gospodarczego, Komunikat Komisji do Parlamentu Europejskiego, Rady, Europejskiego Komitetu Ekonomiczno-Społecznego i Komitetu Regionów, Bruksela 17.07.2012, $\mathrm{KOM}(2012) 392$ wersja ostateczna, [dostęp: 29.06.2015], http://ec.europa.eu/ transparency/regdoc/rep/1/2012/PL/1-2012-392-PL-F1-1.Pdf.

Zielona Księga Europejska Przestrzeń Badawcza: Nowe perspektywy, Bruksela 4.04.2007, $\operatorname{KOM}(2007) 161$ wersja ostateczna, [dostęp: 29.06.2015], https://ec.europa.eu/research/ era/pdf/era_gp_final_pl.pdf. 